\title{
Synthesis and properties of cobalt(II) coordination polymers linked by 4'-(4- pyridyl)-2,2':6',2'-terpyridine
}

Olga Drath ${ }^{\mathrm{a}}$, Robert W. Gable ${ }^{\mathrm{a}}$, Boujemaa Moubaraki ${ }^{\mathrm{b}}$, Keith S. Murray ${ }^{\mathrm{b}}$, Colette Boskovic $^{\mathrm{a}, *}$

a School of Chemistry, University of Melbourne, Parkville, VIC, 3010, Australia

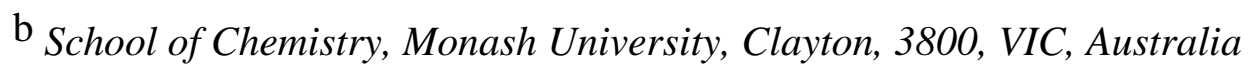

Dedicated to Professor Spyros Perlepes on the occasion of his $65^{\text {th }}$ birthday.

\begin{abstract}
The cationic one-dimensional coordination polymers $\left[\left\{\mathrm{Co}(\text { pyterpy })_{2}\right\}\left\{\mathrm{M}(\mathrm{hfac})_{2}\right\}\right]^{2+}(\mathrm{M}=\mathrm{Co}(\mathrm{II})$ or $\mathrm{Zn}(\mathrm{II})$; pyterpy = 4'-(4-pyridyl)-2,2':6',2"-terpyridine; $\mathrm{hfac}^{-}=$hexafluoroacetyloacetonate) feature alternating $\left\{\mathrm{Co}(\text { pyterpy })_{2}\right\}$ and $\left\{\mathrm{M}(\mathrm{hfac})_{2}\right\}$ units linked through heteroditopic pyterpy ligands. Cocrystallization with $\left[\mathrm{M}(\mathrm{hfac})_{3}\right]^{-}(\mathrm{M}=\mathrm{Co}(\mathrm{II})$ or $\mathrm{Zn}(\mathrm{II}))$ counteranions has afforded the compounds: $\quad\left[\left\{\mathrm{Co}(\text { pyterpy })_{2}\right\}\left\{\mathrm{Co}(\mathrm{hfac})_{2}\right\}\right]\left[\mathrm{Co}(\mathrm{hfac})_{3}\right]_{2} \quad$ (1) and $\left[\left\{\mathrm{Co}(\text { pyterpy })_{2}\right\}\left\{\mathrm{Co}_{0.7} \mathrm{Zn}_{0.3}(\mathrm{hfac})_{2}\right\}\right]\left[\mathrm{Zn}(\mathrm{hfac})_{3}\right]_{2}(\mathbf{2})$. Variable temperature crystallographic and magnetic studies indicate low spin cobalt(II) ions in the $\left\{\mathrm{Co}(\text { pyterpy })_{2}\right\}$ components of the coordination polymers up to room temperature; magnetic studies suggest the onset of a thermallyinduced spin crossover at these centers above room temperature.
\end{abstract}


Keywords: coordination polymers; cobalt; spin crossover; terpyridine

\section{Introduction.}

Coordination polymers (CPs) that exhibit functionality based on electronic and/or magnetic properties are of interest for applications in advanced materials for sensors and display devices. Promising candidates are CPs based on cobalt(II) that can exhibit functionality related to spin crossover and/or intramolecular electron transfer [1,2]. Thermally-stimulated spin crossover (SCO) from low spin (LS) to high spin (HS) states occurs when, as the temperature is raised, the HS state is stabilized relative to the LS so that above a critical temperature the HS state becomes the thermodynamic ground state [3]. The SCO is entropically driven by the higher vibrational and electronic entropy of the HS state, versus the larger enthalpy of the LS state. In some cases, a structural phase transition accompanies the SCO. To date, SCO has been reported for only a handful of cobalt CPs [4-8]. One of these families of SCO CPs has the general formula $\left[\mathrm{CoX}_{2}\right.$ (pyterpy)] where $\mathrm{X}=\mathrm{Cl}^{-}, \mathrm{Br}^{-}$or $\mathrm{NCS}^{-}$and pyterpy $=4^{\prime}$-(4-pyridyl)-2,2':6',2"-terpyridine $[4,7,8]$. The $\mathrm{N}_{4}$-donor heteroditopic pyterpy ligand links the cobalt centers such that they all have the same coordination sphere: chelated by the terpyridyl group of one pyterpy ligand with another pyterpy coordinated monodentate through the pendant pyridyl group (Fig. 1, top). Another structural family of 1D CPs based on pyterpy linkers has also been developed, of general formula $\left[\left\{\mathrm{Ni}(\text { pyterpy })_{2}\right\}\left\{\mathrm{Co}(\beta \text {-diketonate })_{2}\right\}\right]^{2+}$ where $\beta$-diketonate $=$ hexafluoroacetyloacetonate $\left(\mathrm{hfac}^{-}\right)$

or 3-cyanocetyloacetonate [9]. In these two-component $\mathrm{CPs}\left\{\mathrm{Ni}(\text { pyterpy })_{2}\right\}$ and $\{\mathrm{Co}(\beta$ diketonate $\left.)_{2}\right\}$ units alternate along the $1 \mathrm{D}$ chain with the nickel centers each coordinated to two terpyridyl groups of the pyterpy ligands, while the pendant pyridyl groups bind mondentate to the 
cobalt centers of the $\left\{\mathrm{Co}(\beta \text {-diketonate) })_{2}\right\}$ units (Fig. 1, bottom). Magnetochemical characterization of these compounds has not been reported.

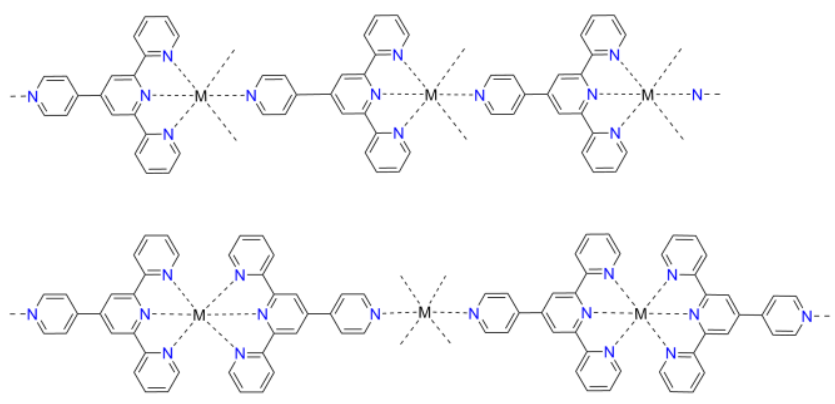

Fig. 1. Different linking modes of the pyterpy ligand in 1D coordination polymers.

Perhaps the largest family of cobalt(II) complexes to exhibit SCO are those derived from $\left[\mathrm{Co}(\text { terpy })_{2}\right]^{2+}$ (terpy $=2,2^{\prime}: 6^{\prime}, 2^{\prime \prime}-$ terpyridine $)[10-14]$. Some, but not all, salts of these complexes exhibit thermally-induced SCO. These processes are generally gradual, reflecting the small structural changes that accompany the switch from LS-cobalt(II) to HS-cobalt(II), while the characteristics of the SCO process can also be dependent on supramolecular interactions. Inspired by the SCO behavior exhibited by related mononuclear $\left[\mathrm{Co}(\text { pyterpy })_{2}\right]^{2+}$ complexes $[15]$ and the known two-component $\left[\left\{\mathrm{Ni}(\text { pyterpy })_{2}\right\}\left\{\mathrm{Co}(\beta \text {-diketonate })_{2}\right\}\right]^{2+} \mathrm{CPs}[9]$, we sought to synthesize analogous two-component CPs that incorporate $\left.\{\mathrm{Co} \text { (pyterpy })_{2}\right\}$ units, with a view to investigating possible SCO processes. Herein we report the synthesis and investigation of $\left[\left\{\mathrm{Co}(\text { pyterpy })_{2}\right\}\left\{\mathrm{Co}(\mathrm{hfac})_{2}\right\}\right]\left[\mathrm{Co}(\mathrm{hfac})_{3}\right]_{2}$ and

$\left[\left\{\mathrm{Co}(\text { pyterpy })_{2}\right\}\left\{\mathrm{Co}_{0.7} \mathrm{Zn}_{0.3}(\text { hfac })_{2}\right\}\right]\left[\mathrm{Zn}(\text { hfac })_{3}\right]_{2}(\mathbf{2})$.

\section{Materials and methods.}




\subsection{Synthesis.}

All manipulations were performed under aerobic conditions. All the reagents were obtained from commercial sources and were used as received. The pyterpy ligand, $\left[\mathrm{Co}(\mathrm{hfac})_{2}\left(\mathrm{H}_{2} \mathrm{O}\right)_{2}\right]$ and $\left[\mathrm{Zn}(\mathrm{hfac})_{2}\left(\mathrm{H}_{2} \mathrm{O}\right)_{2}\right]$ were synthesized according to literature procedures [16][17].

\subsection{1. [\{Co(pyterpy $\left.\left.)_{2}\right\}\left\{\mathrm{Co}(\text { hfac })_{2}\right\}\right]\left[\mathrm{Co}(\mathrm{hfac})_{3}\right]_{2}(\mathbf{1})$.}

Solid pyterpy $(0.12 \mathrm{~g}, 0.40 \mathrm{mmol})$ was added to a suspension of $\mathrm{CoSO}_{4} \cdot \mathrm{H}_{2} \mathrm{O}(0.035 \mathrm{~g}, 0.20$ $\mathrm{mmol})$ in $\mathrm{MeOH} / \mathrm{H}_{2} \mathrm{O}(50 \mathrm{ml}, 4: 1)$ and heated under reflux for $2 \mathrm{~h}$. The resulting dark red solution was filtered while hot and a solution of $\left[\mathrm{Co}(\mathrm{hfac})_{2}\left(\mathrm{H}_{2} \mathrm{O}\right)_{2}\right](0.40 \mathrm{mmol}, 0.20 \mathrm{~g})$ in $\mathrm{MeOH}(5 \mathrm{ml})$ was added. The combined solution was refluxed for another hour, then cooled to room temperature and left to evaporate slowly. After 10 days a dark-red crystalline product was obtained, which was collected by filtration, washed with cold methanol and air dried $(53 \%$ yield $)$. IR $(\mathrm{KBr})\left(v_{\max }, \mathrm{cm}^{-1}\right)$ : 3500(s), 1642(s), 1612(w), 1554(m), 1527(s), 1504(m), 1415(w), 1267(s), 1205(s), 1145(s), 792(m), 670(m), 582(m). Anal. calcd. (\%) for $\mathrm{C}_{80} \mathrm{H}_{36} \mathrm{~N}_{8} \mathrm{O}_{16} \mathrm{~F}_{48} \mathrm{Co}$ : $\mathrm{C}, 38.2 ; \mathrm{H}, 1.4 ; \mathrm{N}$, 4.5. Found: C, 38.5; H, 1.5; N, 4.2.

\subsection{2. $\left[\left\{C o(\text { pyterpy })_{2}\right\}\left\{C o 0.7 Z n_{0.3}(h f a c)_{2}\right\}\right]\left[Z n(h f a c)_{3}\right]_{2}(2)$.}

This compound was synthesized by the same procedure as $\mathbf{1}$, using $\left[\mathrm{Zn}(\mathrm{hfac})_{2}\left(\mathrm{H}_{2} \mathrm{O}\right)_{2}\right]$. (0.40 mmol, $0.20 \mathrm{~g})$ in $\mathrm{MeOH}(5 \mathrm{ml})$, affording a dark-red crystalline product (41\% yield). IR $(\mathrm{KBr})\left(\mathrm{v}_{\max }, \mathrm{cm}^{-1}\right):$ 3500(s), 1644(s), 1611(w), 1554(m), 1527(s), 1509(m), 1408(w), 1269(s), 1208(s), 1149(s), 793(m), 672(m), 586(m(. Anal. calcd (\%) for $\mathrm{C}_{80} \mathrm{H}_{36} \mathrm{~N}_{8} \mathrm{O}_{16} \mathrm{~F}_{48} \mathrm{Co}_{1.7} \mathrm{Zn}_{2.3}$ : C, 38.0; H, 1.4; N, 4.4. Found: C, 38.2; H, 1.5; N, 4.3. Inductively coupled plasma-optical emission 
spectrometry (ICP-OES): found (\%) Co, 3.1; Zn 4.8; giving a mole ratio of approximately Co:Zn $=1.7: 2.3$.

\subsection{Magnetic measurements}

Variable temperature magnetic susceptibility measurements were performed with a Quantum Design MPMS-5 susceptometer, equipped with a $5 \mathrm{~T}$ magnet. Data were collected on powdered, dry crystals restrained in eicosane in a gelatin capsule. Susceptibility data were collected with a magnetic field of 1000 Oe. The data were corrected for the contribution from the eicosane and the gelatin capsule. Pascal's constants were used to estimate the diamagnetic correction for each complex and correct the calculated molar susceptibility values.

\subsection{Inductively coupled plasma optical emission spectroscopy (ICP-OES)}

The ICP-OES measurement was performed at the University of Melbourne Trace Analysis for Chemical, Earth and Environmental Sciences Platform using a Perkin Elmer Optima dv8300 spectrophotometer. A solid sample of $\mathbf{2}(0.068 \mathrm{~g})$ was digested in $1 \mathrm{ml}$ of aqua regia $\left(\mathrm{HCl}: \mathrm{HNO}_{3}\right.$, 3:1) for $5 \mathrm{~h}$ at $100^{\circ} \mathrm{C}$, then cooled to room temperature and diluted to $10 \mathrm{ml}$ with water. The aliquots of the digestate were diluted 5 and 10 times and the spectra registered for two different wavelengths per metal (228.6 nm and 230.8 for Co, $202.5 \mathrm{~nm}$ and $206.2 \mathrm{~nm}$ for $\mathrm{Zn}$ ). Although only $\sim 80 \%$ digestion could be achieved, the results across different dilutions and wavelengths were similar and within the acceptable deviation range of $10 \%$.

\subsection{Other physical measurements}


Elemental analyses were performed by the Campbell Microanalytical Laboratory, Department of Chemistry, University of Otago, New Zealand. Thermogravimetric analyses were performed on a Mettler Toledo thermal analyzer. Infrared spectra ( $\mathrm{KBr}$ disk) were recorded on a Bruker Tensor 27 FTIR spectrometer. Ultraviolet-visible absorption spectra were measured on a Varian Cary50 Bio UV-visible spectrometer and diffuse reflectance spectra were measured on a Thermo Scientific-Evolution 220 UV-Visible spectrophotometer. The powder X-ray diffraction data were acquired at $130 \mathrm{~K}$ on a Rigaku Oxford Diffraction SuperNova diffractometer using CuK $\alpha$ radiation $(\lambda=1.54184 \AA$ ), operated at $50 \mathrm{kV}$ and $40 \mathrm{~mA}$; data were collected with $2 \theta$ angles in the range $5-50^{\circ}$.

\subsection{X-ray crystallography}

X-ray diffraction data for $\mathbf{1}$ were collected at $130 \mathrm{~K}$ on an Rigaku Oxford Diffraction SuperNova single crystal diffractometer using $\mathrm{CuK} \alpha$ radiation. X-ray diffraction data for $\mathbf{2}$ were collected at $100,150,200,250$ and $300 \mathrm{~K}$ using synchrotron radiation, the wavelength approximating MoK $\alpha$ radiation, on the MX1 beamline, at the Australian Synchrotron, Victoria, Australia [18]. Data collection and structure refinement details are summarized in Table 1. All structures were solved using the OLEX ${ }^{2}$ [19] software with the ShelXT [20] structure solution program using intrinsic phasing and refined with the ShelXL refinement package using least squares minimization. Anisotropic displacement values were applied to all non-hydrogen atoms. Hydrogen atoms were included in the refinement, restrained to geometric estimates. One of the $\mathrm{hfac}^{-} \mathrm{CF}_{3}$ groups was disordered over two positions, these atoms were restrained to ideal geometry with similar displacement parameters. During the refinement, distance restraints were applied to some of the carbon atoms. For 2 at $300 \mathrm{~K}$, the displacement parameters of the $\mathrm{CF}_{3}$ groups were 
larger than those observed at lower temperatures, and a second $\mathrm{CF}_{3}$ group was modelled as being disordered over two orientations, while it was necessary to include a number of geometrical restraints to ensure reasonable geometry. The ICP-OES analysis indicated that the $\left\{\mathrm{M}(\mathrm{hfac})_{2}\right\} \mathrm{CP}$ site is $70 \% \mathrm{Co}$ and $30 \% \mathrm{Zn}$. The structural refinement of this site, as a mixture of Co \& $\mathrm{Zn}$, gave values consistent with this analysis (the zinc occupancy at $100 \mathrm{~K}$ was $0.34(5)$, at $150 \mathrm{~K}: 0.15(6)$ and at $200 \mathrm{~K}: 0.39(6)$, averaging to $30 \% \mathrm{Zn}$ occupancy). Since the same crystal was used throughout the variable temperature structural analysis, the occupancy of the site was fixed as $30 \%$ $\mathrm{Zn}$ and $70 \%$ Co for all refinements, consistent with the analysis of the bulk sample. The crystals of both 1 and 2 were found to be merohedral twins, the final twin ratios refining to 0.8920(18):0.1080(18) and 0.6473(17):0.3527(17), respectively. 


\section{Table 1.}

Crystallographic data for $\mathbf{1}$ at $130 \mathrm{~K}$ and $\mathbf{2}$ at 100, 150, 200, 250 and $300 \mathrm{~K}$.

\begin{tabular}{|c|c|c|c|c|c|c|}
\hline Parameter & $1 @ 130 \mathrm{~K}$ & $2 @ 100 \mathrm{~K}$ & $2 @ 150 \mathrm{~K}$ & $2 @ 200 \mathrm{~K}$ & $2 @ 250 \mathrm{~K}$ & $2 @ 300 \mathrm{~K}$ \\
\hline Formula & $\mathrm{C}_{80} \mathrm{H}_{36} \mathrm{~N}_{8} \mathrm{Co}_{4} \mathrm{~F}_{48} \mathrm{O}_{16}$ & \multicolumn{5}{|c|}{$\mathrm{C}_{80} \mathrm{H}_{44} \mathrm{~N}_{8} \mathrm{Co}_{1.7} \mathrm{Zn}_{2.3} \mathrm{~F}_{48} \mathrm{O}_{16}$} \\
\hline $\begin{array}{l}\text { Formula weight } \\
/ \mathrm{g} \mathrm{mol}^{-1}\end{array}$ & 2520.95 & \multicolumn{5}{|c|}{2527.70} \\
\hline Crystal system & tetragonal & \multirow{2}{*}{\multicolumn{5}{|c|}{$\begin{array}{l}\text { tetragonal } \\
\qquad P 4_{2}\end{array}$}} \\
\hline Space group & $P 4_{2}$ & & & & & \\
\hline$a=b / \AA$ & $21.8648(4)$ & $21.924(3)$ & $21.956(3)$ & $21.984(3)$ & $22.011(3)$ & $22.049(3)$ \\
\hline$c / \AA$ & $19.8685(6)$ & $19.926(4)$ & $19.912(4)$ & $20.040(4)$ & $20.198(4)$ & $20.350(4)$ \\
\hline$V / \AA^{3}$ & $9498.5(5)$ & $9577(3)$ & $9599(3)$ & $9685(3)$ & $9786(3)$ & $9895(4)$ \\
\hline$Z$ & 4 & 4 & 4 & 4 & 4 & 4 \\
\hline Temperature / K & $130 \mathrm{~K}$ & $100 \mathrm{~K}$ & 150 & 200 & 250 & 300 \\
\hline$\rho_{\text {calc }} / \mathrm{g} \mathrm{cm}^{-3}$ & 1.757 & 1.753 & 1.749 & 1.733 & 1.716 & 1.697 \\
\hline$\mu / \mathrm{mm}^{-1}$ & 6.863 & 1.019 & 1.016 & 1.007 & 0.997 & 0.986 \\
\hline $\mathrm{F}(000)$ & 4992.0 & 4988.0 & 4988.0 & 4988.0 & 4988.0 & 4988.0 \\
\hline Radiation & $\mathrm{CuK} \alpha$ & Synchrotron & Synchrotron & Synchrotron & Synchrotron & Synchrotron \\
\hline Wavelength / $\AA$ & 1.5418 & 0.71073 & 0.71073 & 0.71073 & 0.71073 & 0.71073 \\
\hline $2 \Theta$ range for data collection $/{ }^{\circ}$ & 7.244 to 130.702 & 2.044 to 63.95 & 2.046 to 64.176 & 1.852 to 63.954 & 1.85 to 63.882 & 1.846 to 63.932 \\
\hline Reflections measured & 51784 & 181430 & 183688 & 183748 & 185737 & 188202 \\
\hline Unique reflections & 15503 & 28291 & 28471 & 28534 & 28844 & 29131 \\
\hline Data / restraints / parameters & $15503 / 19 / 1416$ & $28291 / 80 / 1424$ & $28471 / 92 / 1423$ & $28534 / 82 / 1424$ & $28844 / 87 / 1424$ & $29131 / 225 / 1454$ \\
\hline$R_{\text {int }}$ & 0.0688 & 0.0651 & 0.0894 & 0.0758 & 0.0745 & 0.0744 \\
\hline$R_{1}[I>2 \sigma(I)]$ & 0.0768 & 0.0650 & 0.0673 & 0.0634 & 0.0585 & 0.0608 \\
\hline$w R_{2}$ (all data) & 0.2159 & 0.1930 & 0.2131 & 0.2004 & 0.1845 & 0.1900 \\
\hline Goodness-of-fit on $F^{2}$ & 1.026 & 1.033 & 1.003 & 1.009 & 1.008 & 0.991 \\
\hline$\Delta \rho_{\max , \min } / \mathrm{e} \AA^{-3}$ & $0.82 /-0.35$ & $1.50 /-0.35$ & $0.86 /-0.54$ & $0.89 /-0.49$ & $0.72 /-0.55$ & $0.73 /-0.46$ \\
\hline
\end{tabular}




\section{Results and discussion.}

\subsection{Synthesis and inductively coupled plasma optical emission spectroscopy (ICP-OES).}

Compounds $\mathbf{1}$ and $\mathbf{2}$ were synthesized by slight adaptations of the literature procedure for $\left[\left\{\mathrm{Ni}(\text { pyterpy })_{2}\right\}\left\{\mathrm{Co}(\mathrm{hfac})_{2}\right\}\right]\left[\mathrm{Co}(\mathrm{hfac})_{3}\right][9]$. Crystals of both compounds form in good yield when methanol/water solutions of $\left[\mathrm{Co}(\text { pyterpy })_{2}\right] \mathrm{SO}_{4}$ and $\left[\mathrm{Co}(\mathrm{hfac})_{2}\left(\mathrm{H}_{2} \mathrm{O}\right)_{2}\right]\left(\right.$ or $\left[\mathrm{Zn}(\mathrm{hfac})_{2}\left(\mathrm{H}_{2} \mathrm{O}\right)_{2}\right]$ for 2) are slowly evaporated over 10 days. The purity of $\mathbf{1}$ and $\mathbf{2}$ was confirmed by elemental analysis. Thermogravimetric measurements (Fig. S1) indicate the bulk compounds are solvent free and powder X-ray diffraction patterns (Fig. S2) are nearly identical for isomorphous $\mathbf{1}$ and $\mathbf{2}$ and in excellent agreement with the patterns calculated from single crystal X-ray diffraction data.

The motivation for the synthesis of compound 2 was to replace all the cobalt(II) cations in both the $\left\{\mathrm{Co}(\mathrm{hfac})_{2}\right\} \mathrm{CP}$ units and $\left[\mathrm{Co}(\mathrm{hfac})_{3}\right]^{-}$counterions of $\mathbf{1}$ with diamagnetic zinc(II) centers to remove their magnetic contribution and study magnetic properties of the $\left\{\mathrm{Co}(\text { pyterpy })_{2}\right\}$ unit in isolation (see later). The target mixed-metal $\mathrm{CP}$ was thus $\left[\left\{\mathrm{Co}(\text { pyterpy })_{2}\right\}\left\{\mathrm{Zn}(\mathrm{hfac})_{2}\right\}\right]\left[\mathrm{Zn}(\mathrm{hfac})_{3}\right]$. Although it is not possible to reliably distinguish the cobalt:zinc ratio in a mixed metal site by crystallographic means, due to their similar size, ICP-OES measurements suggest a Co: $\mathrm{Zn}$ ratio in the bulk samples of around 1.7:2.3, rather than the ratio of 1: 3 expected for the target compound. This non-integer ratio indicates that partial metal exchange occurs during the ten-day synthesis and crystallization of 2. Classical studies of the lability of bis-terpyridine complexes of divalent $3 \mathrm{~d}$ metals found a rate of exchange for cobalt(II) of $4 \times 10^{-2} \mathrm{~min}^{-1}$, while exchange of zinc(II) was too rapid to determine the rate [21]. Moreover chelate complexes of $\beta$-diketonate ligands with conventionally labile metal ions such as cobalt(II) and zinc(II) undergo rapid ligand exchange in solution [22]. The monodentate coordination of the pendant pyterpy pyridyl group to the $\mathrm{CP}$ 
$\left\{\mathrm{Co}(\mathrm{hfac})_{2}\right\}$ unit suggests this metal site is the most probable for exchange, and in the absence of any definitive evidence, compound $\mathbf{2}$ is formulated with the Co/Zn exchange at this position only. Further elucidation of the metal sites might be achieved by neutron diffraction or X-ray spectroscopy, which is beyond the scope of the present work.

\subsection{Structure description.}

Compounds 1 and 2 crystallize in the chiral tetragonal $P 4_{2}$ space group and are isomorphous with previously reported $\left[\left\{\mathrm{Ni}(\text { pyterpy })_{2}\right\}\left\{\mathrm{Co}(\mathrm{hfac})_{2}\right\}\right]\left[\mathrm{Co}(\mathrm{hfac})_{3}\right]_{2}[9]$. The main component consists of a cationic $1 \mathrm{D}$ linear chain $\mathrm{CP}$ comprised of alternating $\left\{\mathrm{Co}(\text { pyterpy })_{2}\right\}$ and $\left\{\mathrm{M}(\mathrm{hfac})_{2}\right\}(\mathrm{M}=\mathrm{Co} / \mathrm{Zn})$ units, which are positioned such that the pyridyl group is oriented at $47^{\circ}$ to the terpy plane of the pyterpy ligand, affording an apparent twist in each linker (Fig. 2). Viewed down the length of the chain, all the $\left\{\mathrm{Co}(\text { pyterpy })_{2}\right\}$ units are eclipsed with respect to each other, as are all $\left\{\mathrm{M}(\mathrm{hfac})_{2}\right\}$ units. The asymmetric unit is comprised of one $\{\mathrm{Co}$ (pyterpy) $\}$ unit, one $\left\{\mathrm{M}(\mathrm{hfac})_{2}\right\}$ unit and four halves of the $\left[\mathrm{M}(\mathrm{hfac})_{3}\right]^{-}(\mathrm{M}=\mathrm{Co} / \mathrm{Zn})$ counterion. These 1D chains lie along the $b$-axis and are related to each other by a 2 -fold axis situated around the $c$-axis. The chains are arranged such that the $\left\{\mathrm{Co}(\text { pterpy })_{2}\right\}$ unit of one chain lies adjacent to a $\left\{\mathrm{M}(\mathrm{hfac})_{2}\right\}$ unit of the neighboring chain and the interchain Co $\cdots \mathrm{M}$ distance is around $9.5 \AA$. These chains are stacked along the $c$-axis such that, as a result of the $4_{2}$ screw axes, the chains in the next layer lie along the $a$-axis, giving rise to a square grid arrangement of chains when looking down the c-axis (Fig. 3). Between these 1D chains are channels, running along the $a, b$ and $c$-axes (Fig. 3), in which the $\left[\mathrm{M}(\mathrm{hfac})_{3}\right]^{-}$counteranions reside, balancing the charge of the polymeric network. The presence of three identical bidentate ligands confers optical isomerism such that, in the crystals of $\mathbf{1}$ and 2 examined (which represents half the crystals in the bulk samples), for every four $\left[\mathrm{M}(\mathrm{hfac})_{3}\right]^{-}$ 
complexes, one has a $\Delta$ configuration and three have $\Lambda$ configurations (Fig. S3). The counteranions fill the channels between the CPs in such a way that, when viewed down the c-axis, every second channel is filled only with $\Lambda$ enantiomers and the other with 1:1 mixture of $\Lambda \backslash$ enantiomers (Fig. S4).

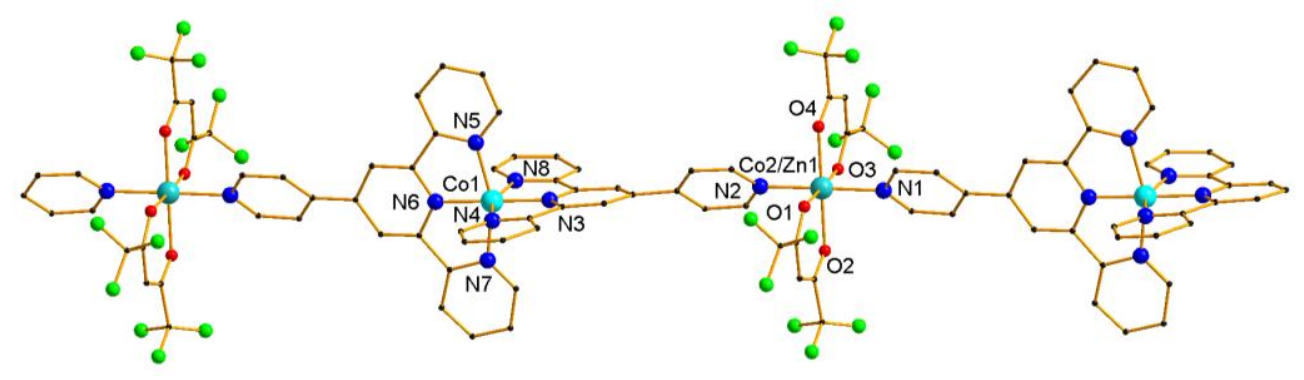

Fig. 2. The chain motif in $\mathbf{1}$ and 2; color code: $\mathrm{Co} / \mathrm{Zn}$ cyan; $\mathrm{O}$, red; $\mathrm{N}$, blue, $\mathrm{C}$, black, $\mathrm{Cl}$, green; hydrogen atoms omitted for clarity; 

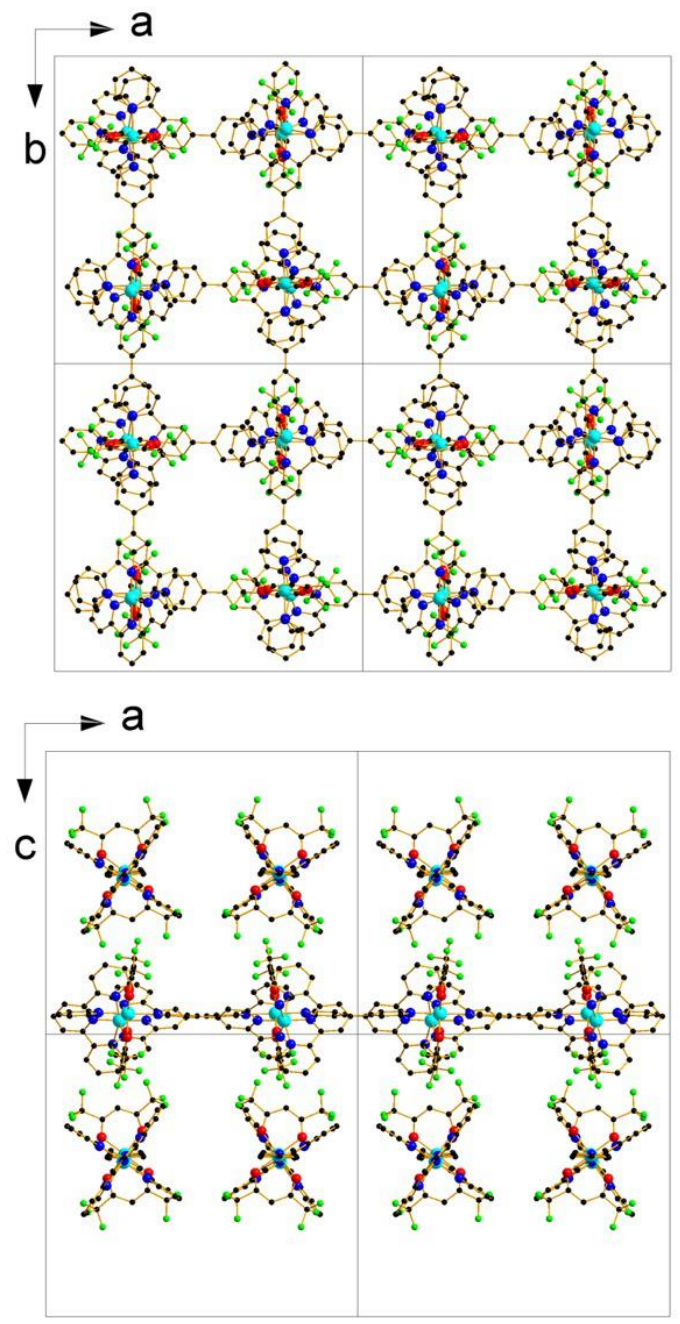

Fig. 3. Crystal packing diagrams of the 1D chains in $\mathbf{1}$ and $\mathbf{2}$; color code as per Fig 2.

Within the CPs of $\mathbf{1}$ and $\mathbf{2}$, both metal(II) centers have distorted octahedral coordination geometry. The bond distances and angles found in $\mathbf{1}$ at $130 \mathrm{~K}$ and $\mathbf{2}$ at $100 \mathrm{~K}$ are very similar. The $\mathrm{Co} / \mathrm{Zn}-\mathrm{O}$ bond lengths for the $\left\{\mathrm{M}(\mathrm{hfac})_{2}\right\} \mathrm{CP}$ units are in the 2.032(13)-2.085(11) $\AA$ range, consistent with previously reported values for hfac ${ }^{-}$complexes of HS-cobalt(II) or zinc(II) ions [23-25]. The $\{\mathrm{Co}$ (pyterpy) $\}$ unit shows significant variation in $\mathrm{Co}-\mathrm{N}$ bond lengths; the two axial bonds (along the chain, N3 and N6) are shorter, in the range 1.87-1.91 $\AA$, while the four equatorial Co-N lengths (N4, N5, N7 and N8) are longer, in the range 2.04-2.12 $\AA$. These bond lengths are 
consistent with low temperature values in the range 1.89-2.24 $\AA$ reported for other LS-cobalt(II) $\left[\mathrm{Co}(\text { terpy })_{2}\right]^{2+}$ and $\left[\mathrm{Co}(\text { pyterpy })_{2}\right]^{2+}$ compounds $[11,12,14,15,26]$. The Co-N bond length differences are not only a consequence of the ligand steric requirements, but also a Jahn-Teller effect for LS-cobalt(II). The distortion from octahedral geometry of the cobalt centers in $\mathbf{1}$ and $\mathbf{2}$ can be parameterized using the SHAPE index calculated from continuous shape measurements (Table 2) [27], as well as from angular distortion parameters $\Sigma$ and $\Theta$ calculated according to equations 1 and 2 [14]:

$$
\begin{aligned}
& \Sigma=\sum_{i=1}^{12}\left|90-\alpha_{i}\right| \\
& \Theta=\sum_{j=1}^{24}\left|60-\theta_{j}\right|
\end{aligned}
$$

where $\alpha_{i}$ are the twelve cis-O/N-Co1-O/N angles about the cobalt atom, $\theta_{j}$ are the 24 unique O/N$\mathrm{C}_{\mathrm{a}}-\mathrm{C}_{\mathrm{b}}-\mathrm{O} / \mathrm{N}$ dihedral angles, $\left|\theta_{j}\right|<120^{\circ}$ and $\mathrm{C}_{\mathrm{a}}$ and $\mathrm{C}_{\mathrm{b}}$ are the centroids of two triangular faces that are opposite on the octahedron such that $\mathrm{C}_{\mathrm{a}}-\mathrm{C}_{\mathrm{b}}$ represents their common pseudo-threefold axis. The $\Sigma$ values of $82.2^{\circ}$ and $74.3^{\circ}$ calculated for 1 at $130 \mathrm{~K}$ and 2 at $100 \mathrm{~K}$, respectively (Table 2), and the corresponding $\Theta$ values of $281^{\circ}$ and $297^{\circ}$, are typical for LS-cobalt(II) in bis-terpyridine cobalt(II) complexes [14]. For reference, at $120 \mathrm{~K}$ the values of $\Sigma$ and $\Theta$ calculated for LS$\left[\mathrm{Co}(\text { terpy })_{2}\right] \mathrm{I}_{2} \cdot 2 \mathrm{H}_{2} \mathrm{O}$ are $92.4^{\circ}$ and $310^{\circ}$, respectively; while $\Sigma$ and $\Theta$ calculated for HS$\left[\mathrm{Co}(\text { terpy })_{2}\right]\left[\mathrm{ClO}_{4}\right]_{2} \cdot 1.3 \mathrm{H}_{2} \mathrm{O}$ at $293 \mathrm{~K}$ are $118^{\circ}$ and $380^{\circ}$, respectively [14]. The calculated SHAPE indices (Table 2) indicates that the coordination geometries of Col in $\mathbf{1}$ and $\mathbf{2}$ are closest to octahedral [27]. 


\section{Table 2.}

Selected interatomic distances $(\AA)$ and distortion parameters for $\left[\left\{\operatorname{Co}(\text { pyterpy })_{2}\right\}\left\{\operatorname{Co}(\mathrm{hfac})_{2}\right\}\right]^{2+}$ in 1 and $\left.\left[\left\{\mathrm{Co}_{(\mathrm{pyterpy}}\right)_{2}\right\}\left\{\mathrm{Co}_{0.7} \mathrm{Zn}_{0.3}(\mathrm{hfac})_{2}\right\}\right]^{2+}$

in 2.

\begin{tabular}{|c|c|c|c|c|c|c|}
\hline Parameters & 1 @ $130 \mathrm{~K}$ & $2 @ 100 \mathrm{~K}$ & $2 @ 150 \mathrm{~K}$ & 2 @ $200 \mathrm{~K}$ & 2 @ $250 \mathrm{~K}$ & $2 @ 300 \mathrm{~K}$ \\
\hline \multicolumn{7}{|l|}{ Distances } \\
\hline $\mathrm{Co} 1-\mathrm{N}_{\mathrm{ax}}{ }^{\mathrm{a}}$ & $1.867(9), 1.872(8)$ & $\begin{array}{l}1.898(6) \\
1.906(6)\end{array}$ & $\begin{array}{l}1.913(7) \\
1.926(9)\end{array}$ & $\begin{array}{l}1.887(6), \\
1.929(7)\end{array}$ & $\begin{array}{l}1.893(6), \\
1.923(6)\end{array}$ & $\begin{array}{l}1.902(6), \\
1.931(6)\end{array}$ \\
\hline Co1- $\mathrm{N}_{\mathrm{eq}}^{\mathrm{b}}$ & $2.040(9)-2.115(11)$ & $\begin{array}{l}2.057(10)- \\
2.119(9)\end{array}$ & $\begin{array}{l}2.079(12)- \\
2.115(14)\end{array}$ & $\begin{array}{l}2.048(10)- \\
2.097(13)\end{array}$ & $\begin{array}{l}2.045(9)- \\
2.101(11)\end{array}$ & $\begin{array}{l}2.065(10)- \\
2.095(10)\end{array}$ \\
\hline $\mathrm{Co} 2 / \mathrm{Zn} 1-\mathrm{O}$ & $2.032(13)-2.085(11)$ & $\begin{array}{l}2.075(8)- \\
2.113(8)\end{array}$ & $\begin{array}{l}2.079(12)- \\
2.117(12)\end{array}$ & $\begin{array}{l}2.083(11)- \\
2.103(10)\end{array}$ & $\begin{array}{l}2.071(9)- \\
2.096(10)\end{array}$ & $\begin{array}{l}2.087(9)- \\
2.102(8)\end{array}$ \\
\hline $\mathrm{Co} 2 / \mathrm{Zn} 1-\mathrm{N}$ & $2.086(9), 2.096(10)$ & $\begin{array}{l}2.059(7) \\
2.079(7)\end{array}$ & $\begin{array}{l}2.071(11), \\
2.082(9)\end{array}$ & $\begin{array}{l}2.073(9) \\
2.080(8)\end{array}$ & $\begin{array}{l}2.083(7) \\
2.086(7)\end{array}$ & $\begin{array}{l}2.088(7) \\
2.106(7)\end{array}$ \\
\hline $\mathrm{Co} 1 \cdots \operatorname{Co} 2 / \mathrm{Zn} 1^{\mathrm{c}}$ & 10.943 & 10.969 & 10.988 & 11.000 & 11.010 & 11.033 \\
\hline $\mathrm{Co} 1 \cdots \mathrm{Co} 2 / \mathrm{Zn} 1^{\mathrm{d}}$ & 9.455 & 9.458 & 9.492 & 9.559 & 9.640 & 10.650 \\
\hline \multicolumn{7}{|c|}{ Distortion parameters $(\mathrm{Co} 1)$} \\
\hline$\Sigma \mathrm{e} /{ }^{\circ}$ & 82.2 & 74.3 & 86.4 & 89.7 & 91.4 & 92.0 \\
\hline$\Theta^{\mathrm{f}} /{ }^{\circ}$ & 281 & 297 & 291 & 301 & 306 & 307 \\
\hline SHAPE $\left(\mathrm{O}_{\mathrm{h}}\right)^{\mathrm{g}}$ & 2.16 & 2.37 & 2.24 & 2.38 & 2.47 & 2.57 \\
\hline
\end{tabular}

${ }^{a}$ axial (N3 and N6).

b equatorial (N4, N5, N7 and N8).

c intrachain.

$\mathrm{d}$ interchain.

e $\Sigma=\sum_{i=1}^{12}\left|90-\alpha_{i}\right|$ where $\alpha_{i}$ are the twelve cis- $\mathrm{O} / \mathrm{N}-\mathrm{Co}-\mathrm{O} / \mathrm{N}$ angles about $\mathrm{Co}$.

${ }^{\mathrm{f}} \Theta=\sum_{j=1}^{24}\left|60-\theta_{j}\right|$ where $\theta_{j}$ are the 24 unique $\mathrm{O} / \mathrm{N}-\mathrm{C}_{\mathrm{a}}-\mathrm{C}_{\mathrm{b}}-\mathrm{O} / \mathrm{N}$ dihedral angles, $\left|\theta_{j}\right|<120^{\circ}$. $\mathrm{C}_{\mathrm{a}}$ and $\mathrm{C}_{\mathrm{b}}$ are the centroids of two triangular faces that are opposite on the octahedron such that $\mathrm{C}_{\mathrm{a}}-\mathrm{C}_{\mathrm{b}}$ represents their common pseudo-threefold axis

${ }^{\mathrm{g}}$ SHAPE index for octahedral geometry, calculated in SHAPE 2.1, the closer the index to zero, the less distortion from $\mathrm{O}_{\mathrm{h}}$ symmetry [27]. 
Structural data for 2 were collected at multiple $(100,150,200,250$ and $300 \mathrm{~K})$ temperatures (Table 2) and structural changes with temperature (Fig. 4 and Fig. S5-S7) examined for signs of a SCO process at the $\{\mathrm{Co}$ (pyterpy) $\} \mathrm{CP}$ unit. Previous variable temperature structural studies of bisterpyridine cobalt(II) complexes have revealed small Co-N bond length changes associated with the cobalt(II) SCO, due to the minimal change in electron configuration from $\mathrm{t}_{2 \mathrm{~g}}{ }^{6} \mathrm{eg}_{\mathrm{g}}{ }^{1}$ to $\mathrm{t}_{2 \mathrm{~g}}{ }^{5} \mathrm{eg}_{\mathrm{g}}{ }^{2}$. In some cases examination of the angular distortion parameters $\Sigma$ and $\Theta$ has proved more informative regarding the SCO process, due to the greater distortion from octahedral geometry for HScobalt(II) versus LS-cobalt(II) [14]. In the case of $\mathbf{2}$, the changes with temperature of the Co-N bond lengths and angular distortion parameters for the $\{$ Co(pyterpy) $\}$ unit are essentially negligible (Fig. 4) and all values remain in the ranges expected for LS-cobalt(II). As expected the $\mathrm{Co} / \mathrm{Zn}-\mathrm{O} / \mathrm{N}$ bond lengths for $\mathrm{Co} 2 / \mathrm{Zn} 1$ in the $\left\{\mathrm{M}(\mathrm{hfac})_{2}\right\} \mathrm{CP}$ units do not change with temperature (Fig S5). The $a$ and $b$ unit cell dimensions, corresponding to the two directions in which the $\mathrm{CP}$ chains run, also remain essentially unchanged with temperature, while a small increase is evident in the $c$ dimension (Fig. S6), which is reflected in a small unit cell volume increase and consistent with thermal expansion (Fig. S7). 

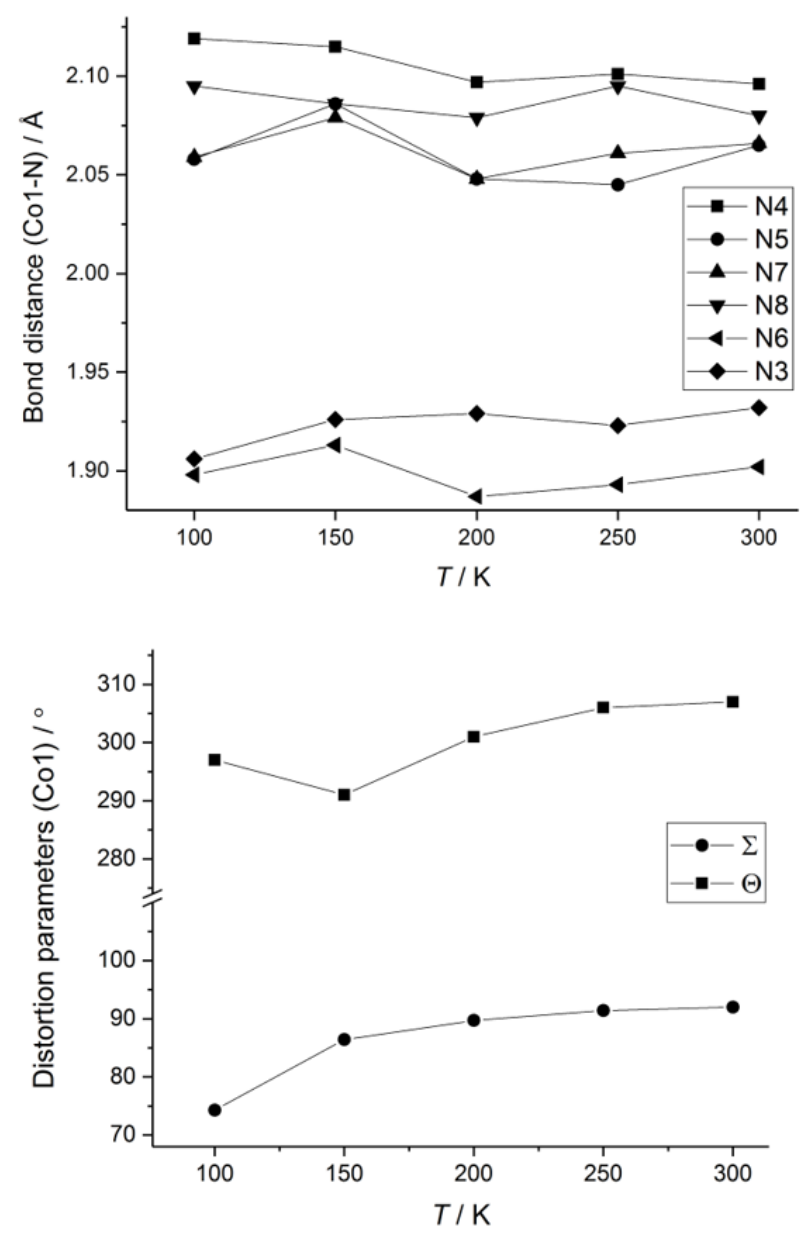

Fig. 4. Plots of structural features of the $\{\mathrm{Co}$ (pyterpy) $\} \mathrm{CP}$ unit of compound 2 as function of temperature: (top) Co1-N bond lengths; (bottom) crystallographic angular distortion parameters for Co1, calculated as indicated in the text.

\subsection{Infrared and $U V$-visible spectroscopy.}

The infrared spectra of $\mathbf{1}$ and $\mathbf{2}$ were collected at room temperature as pressed $\mathrm{KBr}$ pellets (Fig. S8). The spectra of isostructural $\mathbf{1}$ and $\mathbf{2}$ are essentially identical and therefore are discussed together. For both complexes the spectra are dominated by bands corresponding to the $\mathrm{hfac}^{-}$ ligands. In particular, a band at $1642 \mathrm{~cm}^{-1}$ can be attributed to a $\mathrm{C}=\mathrm{O}$ stretch and $1267 \mathrm{~cm}^{-1}$ to a C-F stretch [5]. Bands at 1612 and $1554 \mathrm{~cm}^{-1}$ correspond to $\mathrm{C}=\mathrm{C}$ stretches in $\mathrm{hfac}^{-}$as well as $\mathrm{C}=\mathrm{C}$ 
(aromatic) in pyterpy. Characteristic peaks for both ligands can be found in the fingerprint region: at $792 \mathrm{~cm}^{-1}$ for pyterpy and $670 \mathrm{~cm}^{-1}$ for hfac $[28]$.

The UV-visible diffuse reflectance spectra for $\mathbf{1}$ and $\mathbf{2}$ were collected at room temperature as $\mathrm{KBr}$ solid solutions $(\simeq 3 \%)$. The normalized Kubelka-Munk functions (Fig. S9) are again very similar for the two compounds. The peaks at 312 and $330 \mathrm{~nm}$ correspond to aromatic bands of the pyterpy ligand ( $\pi \rightarrow \pi^{*}$ and $\mathrm{n} \rightarrow \pi^{*}$ ) [29]. Four lower intensity bands in the 400-600 nm range are typical of HS-cobalt(II) $d$ to $d$ transitions [30-32].

\subsection{Magnetic measurements.}

\subsection{1. $\left[\left\{\mathrm{Co}(\text { pyterpy })_{2}\right\}\left\{\mathrm{Co}(\mathrm{hfac})_{2}\right\}\right]\left[\mathrm{Co}(\mathrm{hfac})_{3}\right]_{2}(\mathbf{1})$.}

Magnetic susceptibility data for 1 were measured between 2 and 360 K (Fig. 5) first cooling from $300 \mathrm{~K}$ to $2 \mathrm{~K}$ and then heating to $360 \mathrm{~K}$. The data obtained on heating and cooling are superimposable. The value of the $\chi_{\mathrm{M}} T\left(\chi_{\mathrm{M}}\right.$ is the molar magnetic susceptibility) product at $300 \mathrm{~K}$ is $10.1 \mathrm{~cm}^{3} \mathrm{~mol}^{-1} \mathrm{~K}$, which decreases gradually as the temperature is decreased to $100 \mathrm{~K}$ and then more rapidly, reaching a value of $5.9 \mathrm{~cm}^{3} \mathrm{~mol}^{-1} \mathrm{~K}$ at $2 \mathrm{~K}$. Assuming no $\mathrm{SCO}$ has taken place, the formula unit of the compound is comprised of three HS-cobalt(II) centers and a LS-cobalt(II) center, all of which are distorted octahedral. High spin octahedral cobalt(II) $\left({ }^{4} \mathrm{~T}_{1 \mathrm{~g}}\right)$ is notoriously difficult to model due to the first orbital angular momentum contribution and non-Curie behavior [33]. To assess the $\chi_{\mathrm{M}} T$ profile of $\mathbf{1}$, it is helpful to consider the magnetic susceptibility reported for the HS-cobalt(II) compounds cis-[Co(hfac $\left.)_{2}\left(\mathrm{H}_{2} \mathrm{O}\right)_{2}\right]$ and $\mathrm{Et}_{4} \mathrm{~N}\left[\mathrm{Co}(\mathrm{hfac})_{3}\right]$ by Tsukerblat et al. [24] [23], for which room temperature $\chi_{\mathrm{M}} T$ values are 3.0 and $2.8 \mathrm{~cm}^{3} \mathrm{~mol}^{-1} \mathrm{~K}$, respectively. The

room temperature value of $\chi_{\mathrm{M}} T$ expected for octahedral LS-cobalt(II) $\left({ }^{2} \mathrm{E}_{\mathrm{g}}\right)$ is the $0.38 \mathrm{~cm}^{3} \mathrm{~mol}^{-1} \mathrm{~K}$ expected for a spin-only $S=1 / 2$ system. Thus the $300 \mathrm{~K} \chi_{\mathrm{M}} T$ value of $10.1 \mathrm{~cm}^{3} \mathrm{~mol}^{-1} \mathrm{~K}$ measured 
for $\mathbf{1}$ is consistent with three HS-cobalt(II) and one LS-cobalt(II) ions. The sharp decrease in $\chi_{\mathrm{M}} T$ below $100 \mathrm{~K}$ is also consistent with HS-cobalt(II), due to depopulation of the higher lying Kramers doublets that arise from spin-orbit coupling. Above $300 \mathrm{~K}$ a gradual increase in $\chi_{\mathrm{M}} T$ is evident, reaching a value of $10.4 \mathrm{~cm}^{3} \mathrm{~mol}^{-1} \mathrm{~K}$ at $360 \mathrm{~K}$. This might be indicative of the onset of a SCO process, for the LS Co(II) sites, the profile is often gradual rather than abrupt for cobalt(II), however the data are inconclusive and interpretation is complicated by the presence of the other cobalt(II) centers in the compound.

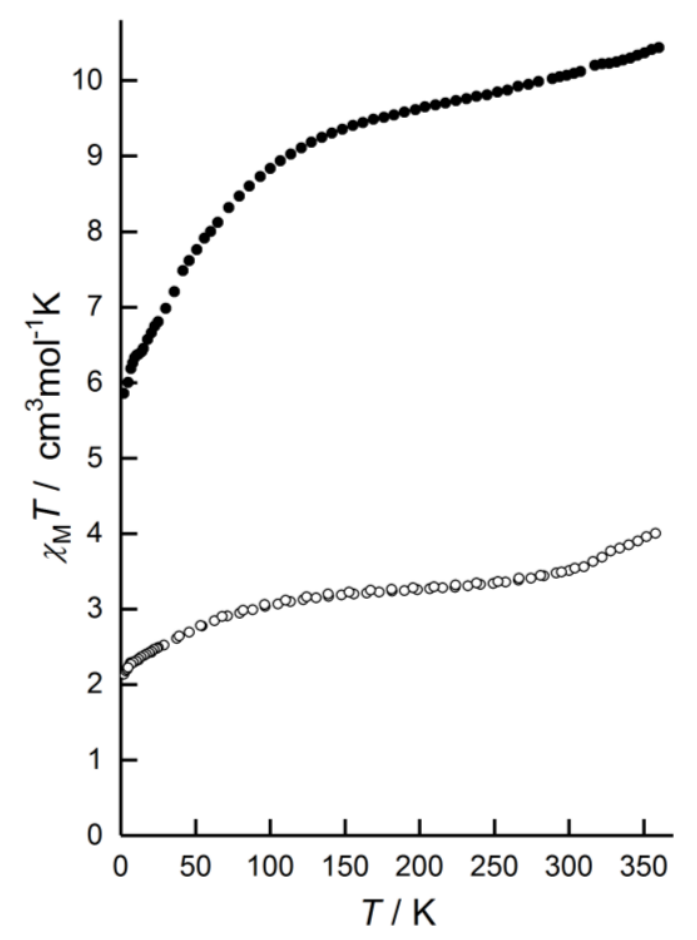

Fig. 5. Plot of $\chi_{M} T$ versus $T$ measured for $\mathbf{1}(\bullet)$ and $\mathbf{2}(0)$ with an applied field of 1000 Oe.

3.4.3. $\left.\left[\{\text { Co(pyterpy })_{2}\right\}\left\{\operatorname{Coo}_{0.7} Z n_{0.3}(h f a c)_{2}\right\}\right]\left[Z n(h f a c)_{3}\right]_{2}(2)$.

Compound 2 was synthesized specifically to remove the contributions to the magnetic susceptibility from the $\mathrm{CP}\left\{\mathrm{Co}(\mathrm{hfac})_{2}\right\}$ units and the $\left[\mathrm{Co}(\mathrm{hfac})_{3}\right]^{-}$counterions, to assess the 
possible $\mathrm{SCO}$ of the $\left\{\mathrm{Co}(\text { pyterpy })_{2}\right\} \mathrm{CP}$ unit in isolation. Although the fully zinc-for-cobalt substituted compound could not be obtained, compound $\mathbf{2}$ has provides better access to the magnetic properties of the $\left\{\mathrm{Co}(\text { pyterpy })_{2}\right\} \mathrm{CP}$ unit. Magnetic susceptibility data for $\mathbf{2}$ were also measured between 2 and $360 \mathrm{~K}$ in cooling and heating mode and again no hysteresis is evident (Fig. 5). The value of $\chi_{\mathrm{M}} T$ of $3.5 \mathrm{~cm}^{3} \mathrm{~mol}^{-1} \mathrm{~K}$ at $300 \mathrm{~K}$ is consistent with one LS-cobalt(II) ion in the $\left\{\mathrm{Co}(\text { pyterpy })_{2}\right\} \mathrm{CP}$ unit, as suggested by variable temperature structural analysis, in addition to $0.7 \mathrm{HS}$-cobalt(II) ions in the $\left\{\mathrm{M}(\mathrm{hfac})_{2}\right\} \mathrm{CP}$ unit. The $\chi_{\mathrm{M}} T$ profile decreases gradually as the temperature is decreased to $100 \mathrm{~K}$ and then more sharply as the sample is cooled further, reaching a value of $2.1 \mathrm{~cm}^{3} \mathrm{~mol}^{-1} \mathrm{~K}$ at $2 \mathrm{~K}$. Qualitatively the profile between 2 and $100 \mathrm{~K}$ is again indicative of some HS-cobalt(II), presumably in the $\left\{\mathrm{M}(\mathrm{hfac})_{2}\right\} \mathrm{CP}$ unit. Upon heating from $300 \mathrm{~K}$ the data for 2 exhibit a definitive increase, with $\chi_{\mathrm{M}} T$ reaching a value of 4.0 at the highest measured temperature of $360 \mathrm{~K}$. This profile is difficult to interpret as due to anything other than the onset of a thermally-induced SCO process at the $\left\{\mathrm{Co}(\text { pyterpy })_{2}\right\} \mathrm{CP}$ unit of 2 above $300 \mathrm{~K}$.

\section{Concluding Remarks.}

The heteroditopic nitrogen-donor ligand pyterpy ligand has been employed as a linking ligand in two new two-component cobalt-based 1D coordination polymers. Variable temperature structural and magnetic studies are consistent with the onset of thermally-induced spin crossover above room temperature at the $\left\{\mathrm{Co}(\text { pyterpy })_{2}\right\}$ units in both compounds, extending the small family of cobalt coordination polymers to exhibit a spin crossover. This work paves the way for future bifunctional multicomponent coordination polymers that undergo spin crossover in one component and exhibit another type of functionality, such as luminescence, valence tautomerism or slow magnetic relaxation, in another component. In principle, the functionality at one component could be used to switch or modulate the functionality at the other component. 


\section{Acknowledgements}

This work was supported by the Australian Research Council (DP150100353). Part of this research was undertaken on the MX1 beamline at the ANSTO Australian Synchrotron, Victoria, Australia

\section{Appendix A. Supplementary data}

CCDC 1832301-1832306 contain the supplementary crystallographic data for $\mathbf{1}$ and $\mathbf{2}$, respectively. These data can be obtained free of charge via http://www.ccdc.cam.ac.uk/conts/retrieving.html, or from the Cambridge Crystallographic Data Centre, 12 Union Road, Cambridge CB2 1EZ, UK; fax: (+44) 1223-336-033; or email: deposit@ccdc.cam.ac.uk. Supplementary data associated with this article can be found, in the online version, at http://dx.doi.org/ XXXX.

\section{References}

[1] O. Drath, C. Boskovic, Coord. Chem. Rev. (2017) doi: 10.1016/j.ccr.2017.11.025..

[2] M.C. Munoz, J.A. Real, Polymeric Spin-Crossover Materials, in: Spin-Crossover Mater. Prop. Appl., 2013: pp. 121-138.

[3] M. A Halcrow, Chem. Commun. 49 (2013) 10890.

[4] S. Hayami, K. Hashiguchi, G. Juhász, M. Ohba, H. Okawa, Y. Maeda, K. Kato, K. Osaka, M. Takata, K. Inoue, Inorg. Chem. 43 (2004) 4124.

[5] K. Bhar, S. Khan, J.S. Costa, J. Ribas, O. Roubeau, P. Mitra, B.K. Ghosh, Angew. Chemie Int. Ed. 51 (2012) 2142.

[6] S. Roy, S. Choubey, K. Bhar, N. Sikdar, J.S. Costa, P. Mitra, B.K. Ghosh, Dalton Trans. 44 
(2015) 7774.

[7] R. Ohtani, K. Shimayama, A. Mishima, M. Ohba, R. Ishikawa, S. Kawata, M. Nakamura, L.F. Lindoy, S. Hayami, J. Mater. Chem. C3 (2015) 7865.

[8] N. Masuhara, S. Hayami, N. Motokawa, A. Shuto, K. Inoue, Y. Maeda, Chem. Lett. 36 (2007) 90 .

[9] J. Yoshida, S. Nishikori, R. Kuroda, Bull. Chem. Soc. Jpn. 82 (2009) 1377.

[10] H.A. Goodwin, Spin Crossover in Cobalt ( II ) Systems, Top. Curr. Chem. 234 (2004) 23.

[11] I. Krivokapic, M. Zerara, M. Daku, A Vargas, C. Enachescu, C. Ambrus, P. Tregennapiggott, N. Amstutz, E. Krausz, A Hauser, Coord. Chem. Rev. 251 (2007) 364.

[12] S. Hayami, Y. Komatsu, T. Shimizu, H. Kamihata, Y.H. Lee, Coord. Chem. Rev. 255 (2011) 1981.

[13] R.G. Miller, S. Narayanaswamy, J.L. Tallon, S. Brooker, New J. Chem. 38 (2014) 1932.

[14] C.A. Kilner, M.A. Halcrow, Dalton Trans. 39 (2010) 9008.

[15] X. Zhang, H. Xie, M. Ballesteros-Rivas, Z.-X. Wang, K.R. Dunbar, J. Mater. Chem. C3 (2015) 9292.

[16] J. Wang, G.S. Hanan, Synlett. 8 (2005) 1251.

[17] R.G. Charles, M.A. Pawlikowski, J. Phys. Chem. 62 (1958) 440.

[18] T.M. McPhillips, S.E. McPhillips, H.-J. Chiu, A.E. Cohen, A.M. Deacon, P.J. Ellis, E. Garman, A. Gonzalez, N.K. Sauter, R.P. Phizackerley, S.M. Soltis, P. Kuhn, J. Synchrotron Radiat. 9 (2002) 401.

[19] O. V. Dolomanov, L.J. Bourhis, R.J. Gildea, J. a K. Howard, H. Puschmann, J. Appl. Cryst. $42(2009) 339$.

[20] G.M. Sheldrick, Acta Cryst. Sect. C71 (2015) 3. 
[21] R. Hogg, R.G. Wilkins, J.Chem.Soc. (1962) 341.

[22] J.R. Hutchison, J.G. Gordon, R.H. Holm, Inorg. Chem. 10 (1971) 1004

[23] A. V. Palii, D. V. Korchagin, E.A. Yureva, A. V. Akimov, E.Y. Misochko, G. V. Shilov, A.D. Talantsev, R.B. Morgunov, S.M. Aldoshin, B.S. Tsukerblat, Inorg. Chem. 55 (2016) 9696.

[24] D. V. Korchagin, A. V. Palii, E.A. Yureva, A. V. Akimov, E.Y. Misochko, G. V. Shilov, A.D. Talantsev, R.B. Morgunov, A.A. Shakin, S.M. Aldoshin, B.S. Tsukerblat, Dalton Trans. 46 (2017) 7540.

[25] S.J. Coles, J. Granifo, M.B. Hursthouse, A.G. Osborne, Acta Cryst. E57 (2001) m535.

[26] S. Aroua, T.K. Todorova, P. Hommes, L.-M. Chamoreau, H.-U. Reissig, V. Mougel, M. Fontecave, Inorg. Chem. 56 (2017) 5930.

[27] S. Alvarez, D. Avnir, M. Llunell, M. Pinsky, New J. Chem. 26 (2002) 996.

[28] M.L. Morris, R.W. Moshier, R.E. Sievers, Inorg. Chem. 2 (1963) 411.

[29] I. Bhowmick, D.J. Boston, R.F. Higgins, C.M. Klug, M.P. Shores, T. Gupta, Sensors Actuators, B Chem. 235 (2016) 325.

[30] L. Banci, A. Bencini, C. Benelli, D. Gatteschi, C. Zanchini, Struct.Bonding. 52 (1982) 37.

[31] J. Narayanan, A. Solano-Peralta, V.M. Ugalde-Saldivar, R. Escudero, H. Höpfl, M.E. SosaTorres, Inorg. Chim. Acta. 361 (2008) 2747.

[32] A. Bencini, A. Beni, F. Costantino, A. Dei, D. Gatteschi, L. Sorace, Dalton Trans. (2006) 722.

[33] F. Lloret, M. Julve, J. Cano, R. Ruiz-García, E. Pardo, Inorg. Chim. Acta. 361 (2008) 3432. 